\title{
Health Education Using Booklet Media to Mother's Behavior in Preventing and Treating Sibling Rivalry for Their Children
}

\author{
Ilya Krisnana \\ Department of Maternity and Child \\ Faculty of Nursing Universitas Airlangga \\ Surabaya, Indonesia \\ ilya-k@fkp.unair.ac.id
}

\author{
Iqlima Dwi Kurnia \\ Department of Maternity and Child \\ Faculty of Nursing Universitas Airlangga \\ Surabaya, Indonesia \\ iqlima.dwi.k@fkp.unair.ac.id
}

\author{
Ria Kusuma Dewi \\ Department of Maternity and Child \\ Faculty of Nursing Universitas Airlangga \\ Surabaya, Indonesia \\ ria.kusuma.dewi-2015@fkp.unair.ac.id
}

\begin{abstract}
Sibling rivalry often occurs in children age ranged 1-3 years and at the age of 3-5 years. Its occurrence will be a negative impact on the child if the mother does not have enough knowledge and cannot handle it. This study aims to determine the effect of health education booklets to the mother's behavior in preventing and treating of sibling rivalry of their children. This study used the quasi-experiment method with pre and post control one group design. There were ten samples in each control or treatment group selected using purposive sampling technique. The independent variable was the health education booklet. The dependent variable was the mother's behavior in preventing and treating the sibling rivalry. Data was collected using a questionnaire and observation sheet. The data analysis used was the Wilcoxon Signed Rank test and Mann-Whitney U test. According to the Wilcoxon Signed Rank test, the booklet as a health education media was proven in increasing the mothers' knowledge $(p=0.007)$, attitude $(p=0.005)$ and practice $(p=$ 0.015). The results of Mann-Whitney test showed that there was an effect obtained after the intervention to the mothers' knowledge $(p=0.001)$, attitudes $(p=0.000)$, and practice $(p=$ 0.001). The results showed that the booklet as health education media affects the mother's behavior in preventing and treating the sibling rivalry among children. Therefore, the booklet can be used by health workers to provide counseling in the community health center for children.
\end{abstract}

Keywords—booklet, health education media, sibling rivalry

\section{INTRODUCTION}

Sibling rivalry is a conflict which occurs among siblings, including jealousy, envy, contention, until a fight that can cause tension [1]. Sibling rivalry usually arises when the age difference between siblings is too close. It happens because of the attentions among the children from the parents which is not equal [2]. The ages which commonly trigger sibling rivalry are the distance between 1-3 years old, appeared at the age of 3-5 years old and reappeared at 8-12 years old. The parents had different reactions upon sibling rivalry among their children [1]. Based on Rita [3] there were 66 children (95.7\%) with the sibling rivalry aggressive behavior, and 62 children (89.9\%) were injured in a sibling younger due to the sibling's rivalry.

Based on preliminary studies by interviewing six mothers who have more than one child between 1-3 years old, it was found that all mothers $(100 \%)$ had children with sibling rivalry. All of the mothers $(100 \%)$ answered that their children often fight because of toys, no one not willing to budge, mutual pinching, hitting, pushing, and some have fallen and crying. The mothers did not know the impact on their children if the fight continues without an awareness as well as a proper response from the parents. Five mothers $(83.3 \%)$ in dealing the conflict will be angry then snapped, taking toys competed over, pinching or hitting his older children if cannot dissuade and did not budge at his younger siblings. One mother $(16.6 \%)$ dealt it with the patient and thought that the conflicts among children are something natural, never angry and not pinching or hitting the children. She also said that health education has never been done on the prevention and treatment of the sibling rivalry and mothers were willing to participate if the counseling is provided in community health center.

The emergence of sibling rivalry in children can be caused by both children and parents. The factors from children including a temperamental child, children's ignorant attitude and love for attention or disturb his brother, as well as the difference in age and gender [4,5]. The factors from parents influenced by internal factors namely intelligence, perception, emotion, motivation and knowledge, while the external factors include objects, persons, groups and culture which affected their behavior [6]. The intelligence that is associated with the level of education that will increase parental knowledge and change behavior for the better, where parents know about sibling rivalry will realize that it is natural to happen and be more mature again in preparation for the first child to accept 
the presence of his new sibling. Perception is associated with parents who had always assumed that older must succumb in every respect. Parental perceptions such as these will lead to sibling rivalry as sister feel unappreciated. Motivation relates to the role of parents in providing impetus to the children to come, sometimes like comparing between the two, such as by praising one child, the other children may feel jealous [7]. Other factors that affect the emotions, if parents were better parents emotional restraint with silence or if it can not be silent, blamed both sides at the same time is still better than in blaming one party [8]. Based on the research of Purnamasari [6] in a village, 21 mothers $(67.7 \%)$ had less knowledge about the sibling rivalry. Therefore, the mothers need health education regarding the incident and the children's sibling rivalry, particularly on the prevention and treatment.

According to Chandran [9] in hospitals and health centers of Mangalore, 198 mothers (66\%) were at the age of 26-30 years, a majority of 192 (64\%) had completed high school, and 262 of those $(87 \%)$ were housewives. The majority of 271 mothers $(90.3 \%)$ had enough knowledge about sibling rivalry, and $189(63 \%)$ had a good attitude toward the sibling rivalry. In this cases, the nurses had performed a significant role in creating health awareness, educating the families in improving the approach to children, and guiding families in managing fighting among children. According Notoatmodjo [10] that one of the efforts to influence health behavior individual, group, or society is health education. Health education process towards the achievement of the objectives the promotion influenced by several factors: factors methods, materials and messages [10]. Health education can be conducted by various methods such as a lecture and demonstration. Demonstration method is a way of presenting a notion or idea were carefully prepared to show how to carry out an action, a scene, or show how to use a procedure and targeted health education free to try the procedure shown by the communicator [11]. The delivering messages need a medium so the message can be received clearly [10]. One media which has several advantages is a booklet. It can be read at any time, the book-shaped design and contains relatively much information [12]. Health education using lecture with media booklets and demonstrations about sibling rivalry has never been performed in the community health center for children. According to Lawrence Green and Kreuter, the health promotion program known for their models to assess and follow up (Precede-Proceed Model) [13]. This model examines the issue of human behavior and the factors that influence it, and how to proceed with an effort to change, maintain or improve the behavior to be more positive. Therefore, the researchers were interested in conducting research on the effects of health education using media booklet on mother's behavior in preventing and treating the sibling rivalry in children.

\section{MATERIAL AND METHODS}

The design of this study was quasi-experiment with pre and post control one group design by providing a treatment group and the control group. The population in this study was mothers with children aged under five who have siblings in a community health center in Kertajaya, Surabaya. The sampling used purposive sampling method. The researchers selected the respondents using demographic data sheet with criteria the mothers who have children under five years more than one. The children must feds himself with the age range of 1-3 years, and who were willing to become respondents. The researchers only took the respondents who were able to read and write as many as ten respondents at each of the control group and the treatment group. The statistical analysis of the data was using Wilcoxon signed ranks test and Mann-Whitney test with a significant level of $\alpha<0.05$. This study had been tested and passed the ethical approval by the Ethics Commission Team Faculty of Nursing Universitas Airlangga with the number 262KEPK. Ethical principles applied in this research include the principles of informed, anonymity, confidentiality and the right to justice.

\section{RESULTS}

Based on the results of statistical Wilcoxon Signed Rank test for the level of knowledge in the treatment group showed the significant value of $p=0.007$. It means that in the treatment group were significant between the level of knowledge before and after health education with booklets. Meanwhile, in the control group, the level of knowledge demonstrated the value of $p=0.157$ greater than 0.05 which means that in there was no difference in the level of knowledge between pre-test and posttest. The Mann-Whitney test results obtained the significant value of $p=0.001$, which showed that health education booklets media influence the change of mothers' knowledge in preventing and treating the sibling rivalry among children.

For the attitude, the Wilcoxon Signed Rank test in the intervention group was $\mathrm{p}=0.005$ which showed that the difference between pre and post test was significant. Meanwhile, in the control group, the test was $p=0.257$ or was not significant. Comparing both groups, the Mann-Whitney test for the attitude was $\mathrm{p}=0.001$ or significant. Regarding the practice, the Wilcoxon Signed Rank test for the intervention group was $\mathrm{p}=0.015$ or significant, while the control group got $\mathrm{p}=0.0180$ or not significant. The Mann-Whitney test between both groups was $\mathrm{p}=0.001$ or significant. The details regarding these results are described in Table 1.

\section{DISCUSSION}

The results showed that the mothers' knowledge who received health education with the media of booklets was significantly different to the knowledge of mothers who did not get the health education with booklets media. Thus, the booklets influence the mother's knowledge in preventing and treating sibling rivalry among children. The results showed after the mothers received the health education with booklets media, the treatment group of four people had increased knowledge from the fair category to be good. Five people had a score in a range of 8 to 10 categories of good knowledge, and one respondent who had poor knowledge became fair category be enough, whereas in the control group only one respondent had increasing knowledge from less to moderate. Knowledge in Notoatmodjo [14] is the result of know what happens after people perform a specific sensing of objects. Sensing occurs through human senses, the senses of sight, hearing, smell, taste, and touch. Most of the knowledge gained from the senses of sight $(30 \%)$ and auditory $(20 \%)$. Knowledge domain is very important in shaping a person's actions. The learning process also influences knowledge which is characterized by acquiring 
something new, unknown and not understood, causing someone to get, know, and understand the information provided. This claim to support the results of this research that there is an increased knowledge after being given health education with the provision of media booklet.

Table 1 The knowledge, attitude, and practice of mothers in intervention and control group

\begin{tabular}{|c|c|c|c|c|c|c|c|c|}
\hline & \multicolumn{4}{|c|}{ Intervention Group } & \multicolumn{4}{|c|}{ Control Group } \\
\hline & \multicolumn{2}{|c|}{ Pre } & \multicolumn{2}{|c|}{ Post } & \multicolumn{2}{|c|}{ Pre } & \multicolumn{2}{|c|}{ Post } \\
\hline & $n$ & $\%$ & $n$ & $\%$ & $n$ & $\%$ & $n$ & $\%$ \\
\hline \multicolumn{9}{|l|}{ Knowledge } \\
\hline Good & 5 & 50 & 9 & 90 & 4 & 40 & 7 & 70 \\
\hline Fair & 4 & 40 & 1 & 10 & 4 & 40 & 3 & 30 \\
\hline Poor & 1 & 10 & 0 & 0 & 2 & 20 & 0 & 0 \\
\hline $\begin{array}{c}\text { Wilcoxon } \\
\text { Signed Rank }\end{array}$ & \multicolumn{4}{|c|}{$\mathrm{p}=0.007$} & \multicolumn{4}{|c|}{$\mathrm{p}=0.157$} \\
\hline $\begin{array}{c}\text { Mann- } \\
\text { Whitney }\end{array}$ & \multicolumn{8}{|c|}{$\mathrm{p}=0.001$} \\
\hline \multicolumn{9}{|l|}{ Attitude } \\
\hline Very Strong & 2 & 20 & 10 & 100 & 0 & 0 & 0 & 0 \\
\hline Strong & 8 & 80 & 0 & 0 & 10 & 100 & 10 & 100 \\
\hline Moderate & 0 & 0 & 0 & 0 & 0 & 0 & 0 & 0 \\
\hline Low & 0 & 0 & 0 & 0 & 0 & 0 & 0 & 0 \\
\hline Very Low & 0 & 0 & 0 & 0 & 0 & 0 & 0 & 0 \\
\hline $\begin{array}{c}\text { Wilcoxon } \\
\text { Signed Rank }\end{array}$ & \multicolumn{4}{|c|}{$\mathrm{p}=0.005$} & \multicolumn{4}{|c|}{$\mathrm{p}=0.257$} \\
\hline $\begin{array}{c}\text { Mann- } \\
\text { Whitney }\end{array}$ & \multicolumn{8}{|c|}{$\mathrm{p}=0.001$} \\
\hline \multicolumn{9}{|l|}{ Practice } \\
\hline Good & 1 & 10 & 3 & 30 & 0 & 0 & 0 & 0 \\
\hline Fair & 7 & 70 & 7 & 70 & 7 & 70 & 10 & 100 \\
\hline Poor & 2 & 20 & 0 & 0 & 3 & 30 & 0 & 0 \\
\hline $\begin{array}{c}\text { Wilcoxon } \\
\text { Signed Rank }\end{array}$ & \multicolumn{4}{|c|}{$\mathrm{p}=0.015$} & \multicolumn{4}{|c|}{$\mathrm{p}=0.180$} \\
\hline $\begin{array}{c}\text { Mann- } \\
\text { Whitney }\end{array}$ & \multicolumn{8}{|c|}{$\mathrm{p}=0.001$} \\
\hline
\end{tabular}

According to Notoatmodjo [14], the media is a tool used by educators in delivering educational or teaching material that serves to help and demonstrate something in education or teaching process. One medium that can be used in health education is the booklet. The booklet is a mass communication media that aims to convey promotional messages, suggestions, prohibitions - the prohibition to a mass audience, the form of books, writing and drawing. So the end of that goal is for society as objects understand and obey the message contained in the mass communication media. The advantages of media booklets are using printed media, so the cost is cheaper than using audio and visual media. The booklet can be used any time; the delivery can also be adapted to existing conditions and more detailed and clear because more can review the messages conveyed [15].

Research on media booklet to changing knowledge also has been done before by Ma'munah [15] that get results that are delivered by health education booklets media can influence significantly increase the knowledge of nursing mothers in Puskesmas East Chester. Another study conducted by Bagary et al. [16] that by using media booklet also effective to the improvement of oral health knowledge of children SDN 126 Manado. Another study was also carried out by Fitriastutik [17] that the media booklet is more effective than guessing game images in improved knowledge of dental caries in at SDNegeri
01, 02, and 03 Bandengan Jepara district of Jepara). Some of these studies support that the media booklets in providing health education to improve the knowledge of the respondent.

Provision of health education media booklet was performed by researchers using lecture and demonstration. According to Efendy \& Makhfudli [11] method of demonstration is a way of presenting a notion or idea were carefully prepared to show how to carry out an action, a scene, or show how using a procedure and targeted health education free to try the procedure shown by the communicator. Demonstration method has the advantage including making learning become clearer and more concrete, and more attractive. The learners are encouraged to understand and adjust the theory to reality and may carry out its demonstration, easier to understand something and reduce errors compared to just reading and listen [18]. The research that has been done in providing health education about sibling rivalry one of which is the research Reni [19] on the effect of the method of role play on the behavior of mothers about sibling rivalry to preschoolers in early childhood.

Another thing that also plays a role in changes in the respondents' knowledge improvement is the level of education, where most respondents in the experimental group of 7 people and the control group of 8 people had a high school. The results showed that the treatment group after health education had increased knowledge. However, only one respondent in the control group who had increased knowledge among from less to enough for investigators also provides leaflets in the control group. It corresponds to the opinion of Mubarak [20] that education means the guidance given someone on others to something that they can understand, can not be denied that the higher the level of education a person the easier it is they receive information, and ultimately the more knowledge has. Conversely, if a person's level of education is low, it will hinder the development of one's attitude to receiving information and new values introduced. The same opinion was also expressed Asiah [21] which states that the higher the level of education obtained, the higher the person's level of knowledge and awareness to find more information in adding to the prior knowledge. This statement was in line with Nugroho [22] which obtained the majority of mothers were educated at the high school has a good knowledge about the growth and development in children with the incidence of sibling rivalry in children aged three to five years at a playgroup in Subang West Java.

The results showed that the age of the respondent in the treatment group as much as four respondents aged 30-40 years show is already quite mature age and after being given the media health education booklets, the respondents' knowledge can increase to a good category. The control group by six respondents aged 30-40 years also have a good knowledge of the current post-test done. Age is one factor that can describe the maturity of a person physically, psychologically and socially, so that helps a person in knowledge. Increasing age, also increasing the knowledge that in the can [10].

Good knowledge also obtained in the group treated with respondents code $\mathrm{B} 6, \mathrm{~B} 7$ and also respondents in the control group with code $\mathrm{A} 1, \mathrm{~A} 5$, and $\mathrm{A} 8$. The respondents have 
children amounts to $\geq 3$ and does not work, where respondents nurture and take care of his own unaided by others, and of course, mothers experience will also be more. Homemakers are women who are married, have children, and do not have a job whose activities include washing, cooking and taking care of children [23]. Mothers who do not work will be a lot of experience taking care of children because everyday activities more at home and spend more time with children. It is also supported by the opinion Mubarak [24] that knowledge itself is influenced by education, occupation, age, interests, experience, culture, and information.

Based on the above results the researchers argue that health education is a good activity to increase knowledge. Selection of media booklet as a medium of education can be received well by the mother due to several things including the health education materials contained in media booklet has drawings and attractive colors. It made the respondent does not get bored while reading it, using language that is simple and easy to understand and booklets can bring home to be read again, resulting in increased knowledge of the respondent may occur and will help raise awareness and to influence their attitudes in preventing and sibling rivalry in children.

The results also indicated in the treatment group gained a majority of respondents experienced an increase in change in attitude from the strong category to be very strong, while the control group most respondents did not experience a change of attitude. It means booklets influence on changing attitudes of mothers in the prevention and treatment of sibling rivalry in children.

According Notoatmodjo [14] attitude is a reaction or response which was still closed from a person to a stimulus or object. According to the theory of Green \& Kreuter [25], the attitude became one of the predisposing factors that influence the formation of behavior. Attitude formation is influenced by experience, education, and emotional factors or interactions to the environment. These factors will shape the beliefs, feelings and the tendency of a person to behave. It supports research about not finding respondents who have a lack attitude due to factors that influence attitudes. One of the factors was the education, where most as many as eight respondents in the control group had high school and also largely in the experimental group of 7 people well-educated high school. In that school, the level of education will also increase knowledge, and positive attitudes can change for the better, a parent who knows about sibling rivalry will realize that it is natural to happen and be more mature in preparing the first child to accept the presence of his new sibling. If the acceptance of new behavior or attitude of a person in the face of something new through a process that is based on knowledge, awareness and positive attitude, the nature or the behavior of a lasting nature. We recommend that the attitudes and behaviors that are not based on knowledge and awareness will not last long. For example, parents' attitude in dealing with sibling rivalry that occurs in a toddler in need of knowledge and awareness of parents about sibling rivalry itself, so that parents are ready and able to prevent or minimize sibling rivalry [26].

Theory Green \& Kreuter [25] revealed that health education is one factor in influencing, modify, maintain, or improve the behavior towards more positive. Through health education with the booklet, the manner of the respondent can be improved so they would be able to understand about the prevention and treatment of sibling rivalry on the child. Such knowledge will lead the respondent to think and build emotional and establish the confidence of respondents to be able to change his attitude to a more positive direction. This theory supports the results of studies showing that the majority of respondents experienced an increase in knowledge and change attitudes towards a more positive after being given health education with the provision of media booklet.

Research on the booklet to a change in attitude also has been done before by Apriani et al. [27] which states that there is the influence of health education with the provision of attitude towards wus booklet on early detection of breast cancer in Surakarta Central Java. Another study was also carried out by the Son (2015) who get the result that there is a significant influence in the provision of health education booklets using media on attitudes towards the treatment of leprosy in a city in East Java.

According to investigators, the change in attitude after being given health education media booklet occurs because of the stimulus of health education and media booklet resulting in an increase in the knowledge of the respondent. Thus, the respondent had been able to capture the positive things delivered, understand the information, then form and change the mindset of the respondents to make a good effort in the prevention and treatment of the child's sibling rivalry.

The results also showed that health education media booklets influence the change actions mothers in handling sibling rivalry in children in the case study given, actions mothers who received health education media booklet significantly different compared with the actions of mothers who do not get health education media booklet, and stated that health education booklets media affect the mother's actions in handling sibling rivalry in children IHC Sartika I Puskesmas Pucang Sewu RW 8 Kertajaya-Gubeng Surabaya.

Based on the results at the time before being given health education media booklet majority of respondents in the experimental group of 7 people act reasonably in handling sibling rivalry among children and 2 people perform actions that are lacking and as many as one people have done their actions well, whereas in the control group of 7 people to code respondents doing enough in handling sibling rivalry on a child in a given case study and as many as three respondents take any action that is not good. At the moment after the given health education media booklet in the treatment group changes significant action is largely as much as 7 people doing enough and as many as three people with a code of respondents has done a good action, while respondents in the control group there is a change of action also in the handling of sibling rivalry in children, but did not increase significantly there is shown from the results that the majority of 10 people just doing enough in handling sibling rivalry in children.

Research Roger (1974) in Efendi \& Makhfudli [11] revealed that before a person adopting the new behavior (behavior), in that person happens sequential process, namely the emergence of consciousness (awareness), i.e., the person is 
aware of (knowing) stimulus beforehand, interest (interest), i.e., the person became interested in the stimulus, consider whether or not the stimulus (evaluation), the attitudes of those already better yet, start trying (trial), i.e., the person decided to start trying new behaviors, adapting (adoption ), that the person has recently behaved in accordance with the knowledge, awareness, and his attitude toward the stimulus. This theory supports the results of studies showing that most respondents experienced changes better action against handling sibling rivalry in children in the case study presented after getting stimulus through health education media booklet raises awareness, interest, consider the benefits and want to try to take action more positive in the face of controversy, or sibling rivalry reaction in children with the aim that can be more thoughtful parent and sibling rivalry can change the reaction into a positive impact on the development of children's emotional and social interaction.

Changes action for the handling sibling rivalry mothers of children in a given case study can not achieve the maximum change in either category because the majority does have some constraints such as the seriousness of the respondents in conducting case study vary due to embarrassment, reluctant, or even no who laughed when did it because it was funny to see the scene in the given case study. In addition, many respondents who brought along his son, when the child is fussy, and also follow the case study given the mother looked hassles so that researchers and volunteers participate and help soothe her in a way to hold him beforehand or assist lap and provide some toys to help calm his children to the mother can do case study is given, but sometimes mothers do so with haste.

Further changes in the behavior itself are also determined or formed from several factors, including predisposing factors (predisposing factors) include knowledge, attitudes, beliefs, convictions, age and values, and so on. Factors supporting (enabling factors) embodied in the physical environment, provided or unavailability of facilities or health facilities and the factors driving (reinforcing factor) is a factor which reinforces the behavior, which is manifested in the attitudes and behavior of health workers, peers, old, which is the reference group of people's behavior [12, 24]

The theory also becomes a foundation that supports that change the behavior of mothers in the prevention and treatment of sibling rivalry in children is influenced by many things, but still be a limitation of the study that can not be related to the variable-variables supporter, was limited to the knowledge, attitudes, and actions of mothers in the prevention and treatment of sibling rivalry in children, and researchers are only able to present the results of studies that illustrate that the research investigators in the treatment group did not have the facilities and infrastructure are adequate, including the implementation of the activities health education and case study conducted house or yard cadre, put on the mat, and also chairs yet, if it was already blazing, rather hot and drizzle respondents felt uncomfortable and fussy kids so that focus and concentration in participating in health education are also affected. Expectations of future facilities and infrastructure as one of the factors supporting this behavior change will also be a concern, and better yet, so it will be able to help improve the mother's behavior changes follow Posyandu activities and health education provided.

\section{CONCLUSIONS}

Health education with booklet can improve the mother's knowledge, attitude, and practice through the process of understanding supported by illustrations and interesting colors, shaped books, not quickly torn and storage easy and using simple language that can be understood about the prevention and treatment of sibling rivalry in children. Health education with booklet can change the actions of mothers in handling sibling rivalry children through case study is given, so she has experienced real action in handling sibling rivalry in children wisely and correctly.

\section{REFERENCES}

[1] Setiawati and Dermawan, Proses Pembelajaran dalam Pendidikan Kesehatan. Jakarta: Trans Info Media, 2008.

[2] T. Havnes, "Sibling rivalry over parental care. Intra-household conflict and child investment," University of Oslo, 2010.

[3] Rita and Winarianti, "Hubungan Sibling Rivalry Toddler Dengan Kejadian Cidera Pada Saudara Sekandungnya Di RW 12 Kelurahan Kemiri Kecamatan Beji Kota Depok,” Universitas Indonesia, 2009.

[4] C. Priatna and A. Yulia, Mengatasi persaingan saudara kandung pada anak-anak. Jakarta: PT. Elex Komputindo, 2006.

[5] A. Whitworth and R. Stephenson, "Birth spacing, sibling rivalry and child mortality in India,” Soc. Sci. Med., vol. 55, no. 12, pp. 2107-2119, Dec. 2002.

[6] D. Purnamasari, D. M. Bakara, and Y. Sutriyanti, "Hubungan Tingkat Pengetahuan Ibu dengan Kejadian Sibling Rivalry pada Usia Balita," J. Kesehat., vol. V, pp. 182-188, 2014.

[7] J. Edward, "Sibling Discord: A Force for Growth and Conflict," Clin. Soc. Work J., vol. 41, no. 1, pp. 77-83, Mar. 2013.

[8] S. Notoatmodjo, Pendidikan dan Perilaku Kesehatan. Jakarta: Rineka Cipta, 2003.

[9] A. Chandran, “A Study on Knowledge and Attitude of Mothers Regarding Sibling Rivalry in a Selected Hospital and PHC in Mangalore with the view to Develop a Self Instructional Module," Int. J. Nurs. Educ., vol. 4, no. 2, 2012.

[10] S. Notoatmodjo, Ilmu Perilaku Kesehatan. Jakarta: Rineka Cipta, 2010.

[11] F. Efendi and Makhfudli, Keperawatan Kesehatan komunitas: Teori Dan Praktek Dalam Keperawatan. Jakarta: Salemba Medika, 2009.

[12] Madani, "Pengaruh Pemberian Booklet Terhadap Pengetahuan Dan Sikap Siswa Mengenai Penyalahgunaan Napza Di Sma Negeri 01 Kota Gorontalo," Universitas Negeri Gorontalo, 2014.

[13] Nursalam, Metode Penelitian Ilmu Keperawatan: Pendekatan Praktis, 3rd ed. Jakarta: Salemba Medika, 2014.

[14] S. Notoatmodjo, Promosi Kesehatan dan Perilaku Kesehatan Edisi Revisi. Jakarta: Rineka Cipta, 2012.

[15] M. Ma'munah, "Pengaruh Pendidikan Kesehatan Dengan Booklet Terhadap Pengetahuan Ibu Laktasi Di Wilayah Kerja Puskesmas Ciputat Timur,' Universitas Islam Negeri Syarif Hidayatullah, 2015.

[16] F. E. K. Bagaray, V. N. S. Wowor, and C. N. Mintjelungan, "Perbedaan efektivitas DHE dengan media booklet dan media flip chart terhadap peningkatan pengetahuan kesehatan gigi dan mulut siswa SDN 126 Manado," e-GIGI, vol. 4, no. 2, 2016.

[17] D. R. Fitriastutik, "Efektivitas Booklet Dan Permainan Tebak Gambar Dalam Meningkatkan Pengetahuan Dan Sikap Siswa Kelas IV Terhadap Karies Gigi Di Sd Negeri 01, 02, Dan 03 Bandengan Kecamatan Jepara Kabupaten Jepara Tahun Ajaran 2009/2010," Universitas Negeri Semarang, 2010.

[18] Sanjaya, Strategi Pembelajaran. Jakarta: Kencana Prenada Media, 2006. 
[19] Reni, "Pengaruh Metode Role Play Terhadap Perilaku Ibu Tentang Sibling Rivalry Pada Anak Usia Prasekolah Di Paud Kb Bukit Siwalan Gresik," Universitas Airlangga, 2015.

[20] W. I. Mubarak, Promosi Kesehatan. Yogyakarta: Graha Ilmu, 2007.

[21] M. D. Asiah, "Hubungan Tingkat Pendidikan Dengan Pengetahuan Kesehatan Reproduksi Ibu Rumah Tangga di Desa Rukoh Kecamatan Syiah Kuala Banda Aceh,” Unsyiah Darussalam, pp. 1-4, 2009.

[22] C. A. Nugraha, "Hubungan tingkat pengetahuan ibu tentang tumbuhkembang anak dengan reaksi sibling rivalry pada anak usia tiga sampai lima tahun di TK Assyifa Tanjung Rasa Kidulpatok Beusi Subang Jawa Barat,” Sekolah Tinggi Ilmu Kesehatan Surya Global Yogyakarta, 2008.

[23] Y. Nurhamida, "Power In Marriage Pada Ibu Bekerja Dan Ibu Rumah Tangga,” J. Psikogenes., vol. 1, no. 2, pp. 185-198, Jul. 2015.
[24] W. I. Mubarak, Promosi Kesehatan Untuk Kebidanan. Jakarta: Salemba Medika, 2012

[25] C. M. Porter, "Revisiting Precede-Proceed: A leading model for ecological and ethical health promotion," Health Educ. J., vol. 75, no. 6, pp. 753-764, 2016.

[26] T. Khasanah, "Pengaruh Kesiapan Terhadap Perilaku Orang Tua Dalam Menghadapi Sibling Rivalry (Cemburu) Pada Anak Usia Dini (Di Desa Harjowinangun Barat Kecamatan Tersono Kabupaten Batang)," J. NonFormal Educ. Community Empower., vol. 1, no. 2, 2012.

[27] A. Apriani, M. Lina, and F. Kumalasari, "Pengaruh Pendidikan Kesehatan Dengan Booklet Terhadap Pengetahuan Dan Sikap Pada Wus Di Surakarta Jawa Tengah,” J. KESMADASKA, vol. 6, no. 1, pp. 33-37, 2014. 